DOE/ER/60631--9

DE92 013674

THE RADIOLOGICAL RESEARCH ACCELERATOR FACILITY

Progress Report for the Perlod December 1, 1991-November 30, 1992

By

E. J. Hall

S. A. Marino

May 1992

Work Performed Under Contract No. FG02-88ER60631

College of Physicians \& Surgeons of Columbla University New York, New York 


\section{THE RADIOLOGICAL RESEARCH ACCELERATOR FACILITY}

\section{Progress Report}

for the Period December 1, 1991 - November 30, 1992

E.J. Hall, Principal Investigator and Director

Center for Radiological Research

S.A. Marino, Co-Principal Investigator

Radiological Research Accelerator Facility

Center for Radiological Research

Department of Radiation Oncology

College of Physicians \& Surgeons of Columbia University

Postal Address:

RARAF, Nevis Laboratories

Columbia University

P.O. Box 21

Irvington, NY 10533

May 1992

Prepared for

THE U.S. DEPARTMENT OF ENERGY

UNDER GRANT NO. DE-FG02-88ER60631 


\section{Introduction}

The Radiological Research Accelerator Facility (RARAF) is based on a 4-MV Van de Graaff accelerator, which is used to generate a variety of well-characterized radiation beams for research in radiobiology, radiological physics, and radiation chemistry. It is part of the Center for Radiological Research (CRR) - formerly the Radiological Research Laboratory (RRL) - of Columbia University, and its operation is supported as a National Facility by the U.S. Department of Energy (DOE). As such, RARAF is available to all potential users on an equal basis, and scientists outside the CRR are encouraged to submit proposals for experiments at RARAF. The operation of the Van de Graaff is supported by the DOE, but the research projects themselves must be supported separately.

RARAF was conceived in the mid 1960s by Drs. Victor P. Bond of Brookhaven National Laboratory (BNL) and Harald H. Rossi of Columbia University as a research resource dedicated to radiobiology and radiological physics and was officially established on January 1, 1967. This year marks its 25th anniversary. RARAF's Van de Graaff accelerator originally served as the injector for the Cosmotron, a $2-\mathrm{GeV}$ accelerator operated at BNL in the 1950s and early 1960s. The immediate aim was to provide a source of monoenergetic neutrons for studies in radiation biology, dosimetry, and microdosimetry. In other major projects the energetic ions produced were utilized directly. RARAF was located at BNL from 1967 until 1980, when it was dismantled and moved to the Nevis Laboratories of Columbia University, where it was then reassembled and put back into operation.

Data obtained from experiments using RARAF have been of pragmatic value to radiation protection and neutron therapy. At a more fundamental level, the research at RARAF has provided insight into the biological action of radiation and especially its relation to energy distribution in the cell. High-LET radiations are an agent of special importance because measurable cellular effects can be caused by single particles, eliminating some of the complexities of multievent action and more clearly disclosing basic features. This applies particularly to radiation carcinogenesis. 
Facilities are available at RARAF for exposing objects to different radiations having a wide range of linear energy transfers (LE' '́s). In the track-segment facility, monolayer cultures of cells can be exposed to charged-particle tracks with well-defined LETis from 10 to $200 \mathrm{keV} / \mu \mathrm{nn}$. Cells can be irradiated with spatially correlated pairs or triplets of ions using the molecular-ion facility. There is also a charged-particle beam line for radiological physics or chemistry experiments. The charged-particle beams from the accelerator can be used to produce essentially monoenergetic neutrons in the range $220 \mathrm{keV}$ to $15 \mathrm{MeV}$ and broad-spectrum neutrons with a mean energy as low as $40 \mathrm{keV}$. Low-LET (photon) radiation is provided by a $250-\mathrm{kVcp} \mathrm{X}$-ray machine and a $50-\mathrm{kV} c p \mathrm{X}$-ray machine attached to the track-segment fixture. A new facility is now available to provide soft $x$-rays $(0.3$ to $3 \mathrm{keV})$ using proton-induced $\mathrm{x}$-ray emission (PIXE).

Some of the support facilities available at RARAF include: cell culture laboratories, a minicomputer and a personal computer (PC) for controlling experiments and recording data, a CAMAC data acquisition system, a bio-preparation/animal-holding room, limited electronics for use by experimenters, and office space for users.

Members of the RARAF staff provide a variety of services in addition to operating, maintaining, and developing the accelerator. They perform most irradiations and are responsible for dosimetry and for developing specialized dosimetry devices and methods when needed. They also provide computer support, help design experiments, and do collaborative research with some users. The CRR machine shop is available for the fabrication of necessary dosimetry and irradiation fixtures. Costs for special services and machine shop time are recovered from the user. All principal investigators are encouraged to request funds in their grant applications to cover the cost of accelerator use, unless the funding source is the Office of Health and Environmental Research of DOE.

In addition to the RARAF Staff, other CRR scientists are engaged in collaborative research with outside users of RARAF. Some of the most interesting and complex 
experiments done by outside users have been made possible only by active and significant in-house collaboration far beyond the operation of the accelerator and provision of dosimetry.

The operation of RARAF through 1982 was described in RRL. Annual Progress Reports. From 1983 to 1987, RARAF operated under a separate DOE Contract or Grant (first DE-ACO2-83ER60110, then DE-FG02-86ER60539), and operation of the Facility was described in separate RARAF Progress Reports (1-5). Since 1988 the operation of RARAF has been supported by part of a single grant to the CRR (DE-FG02-88ER60631), but since RARAF is a separate component, the reports are submitted separately (6-9).

\section{RARAF User's Guide}

To increase the utilization of RARAF by scientists outside CRR, a RARAF User's Guide was prepared in 1985 for distribution to potential users. The Guide contains detailed information about the Facility's research capabilities and how to plan an experiment at RARAF, and it includes an Experiment Request Form for submitting proposals for new experiments. The User's Guide was reproduced as an appendix to the RARAF Progress Report for 1985 (3). A copy of the Guide may also be obtained by contacting the Manager of RARAF.

Since the sections of the User's Guide covering the RARAF staff and the Scientific Advisory Committee are currently out of date, new capabilities and facilities are now available, and additional facilities will be available vithin about a year, it is expected that a new User's Guide will be prepared .

\section{Research Using RARAF}

Table 1 lists the experiments performed at RARAF during the period May 1, 1991 through April 30, 1992 and the number of days each was run in this period. The numerical order of experiments is based on the date of submission of the Experiment Request Forms. Fractional days were assigned to experiments when two or more were run on the same day or 
Table 1. Experiments Run at RARAF, May 1, 1991 - April 30, 1992

\begin{tabular}{|c|c|c|c|c|c|}
\hline $\begin{array}{l}\text { Exp. } \\
\text { No. }\end{array}$ & Experimenter & Institution & $\begin{array}{l}\text { Exp. } \\
\text { Type }\end{array}$ & Title of Experiment & $\begin{array}{l}\text { No. } \\
\text { Days } \\
\text { Run }\end{array}$ \\
\hline 10. & P. Kliauga & $\overline{C R R}$ & Phys & $\begin{array}{l}\text { Precision microdosimetry and } \\
\text { nanodosimetry of monoenergetic } \\
\text { neutrons and charged particles of } \\
\text { defined LET }\end{array}$ & 1.0 \\
\hline 12. & B. Worgul & $\begin{array}{l}\text { Columbia } \\
\text { University }\end{array}$ & $\overline{B i o}$ & $\begin{array}{l}\text { Radiation cataractogenesis: The effect } \\
\text { of [neutron] dose and fractionation }\end{array}$ & 4.7 \\
\hline 34. & P. Goldhagen & $\begin{array}{l}\text { Environmental } \\
\text { Measurements } \\
\text { Laboratory }\end{array}$ & Phys & $\begin{array}{l}\text { Variance-covariance measurements of } \\
y_{D} \text { for 6- and 14-MeV neutrons in } \\
\text { spherical sites with a wide range of } \\
\text { sizes }\end{array}$ & 17.5 \\
\hline 37. & D. J. Brenner & $\overline{C R R}$ & $\begin{array}{c}\text { Phys/ } \\
\text { Bio }\end{array}$ & Towards the new $Q$ & 11.0 \\
\hline 41. & $\begin{array}{l}\text { R. C. Miller/ } \\
\text { S. Martin }\end{array}$ & $\overline{\mathrm{CRR}}$ & $\overline{B i o}$ & $\begin{array}{l}\text { Oncogenic transformation induction } \\
\text { by high-LET radiation }\end{array}$ & 11.2 \\
\hline 43. & T. K. Hei & $\overline{C R R}$ & $\overline{\text { Bio }}$ & $\begin{array}{l}\text { Cellular and molecular studies on the } \\
\text { mutagenesis of charged particles using } \\
\text { human-hamster hybrid }\left(A_{L}\right) \text { cells }\end{array}$ & 7.0 \\
\hline 44. & V. P. Bond & $\mathrm{BNL}$ & Bio & $\begin{array}{l}\text { An HSEF for chromosome aberrations } \\
\text { [ in human lymphocytes] }\end{array}$ & 1.5 \\
\hline 45. & A. Pellicer & NYU & Bio & $\begin{array}{l}\text { Oncogene activation and mutagenesis } \\
\text { by neutrons }\end{array}$ & 7.0 \\
\hline 50. & R. C. Miller & $\overline{\text { CRR }}$ & Bio & $\begin{array}{l}\text { Oncogenic transformation as a } \\
\text { function of dose protraction of } \\
\text { particles of defined LET }\end{array}$ & 2.5 \\
\hline 51. & C. R. Geard & CRR & Bio & $\begin{array}{l}\text { Biological effects of short-range } \\
\text { radiations }\end{array}$ & 13.3 \\
\hline
\end{tabular}




\begin{tabular}{|c|c|c|c|c|c|}
\hline $\begin{array}{l}\text { Exp. } \\
\text { No. }\end{array}$ & Experimenter & Institution & $\begin{array}{l}\text { Exp. } \\
\text { Type }\end{array}$ & Title of Experiment & $\begin{array}{l}\text { No. } \\
\text { Days } \\
\text { Run }\end{array}$ \\
\hline 53. & J. C. Willey & $\begin{array}{l}\text { University of } \\
\text { Rochester }\end{array}$ & Bio & $\begin{array}{l}\text { Evaluation of the cytotoxic and } \\
\text { oncogenic transforming effects of } \\
\text { simulated radon daughter products } \\
\text { using human bronchial epithelial cells }\end{array}$ & 6.0 \\
\hline 54. & L.G. Littlefield & $\begin{array}{l}\text { Oak Ridge } \\
\text { Assoc. Univ. }\end{array}$ & Bio & $\begin{array}{l}\text { Cytogenic indices - direct vs indirect } \\
\text { action }\end{array}$ & 4.8 \\
\hline 55. & $\begin{array}{l}\text { R. C. Miller/ } \\
\text { S. Martin }\end{array}$ & CRR & Bio & $\begin{array}{l}\text { Isolation of cells transformed by } \\
\text { neutrons and charged particles of } \\
\text { defined LET }\end{array}$ & 2.7 \\
\hline 56. & R. C. Miller & $\begin{array}{l}\text { St. Barnabas } \\
\text { College }\end{array}$ & Bio & $\begin{array}{l}\text { Transformation of synchronized } \\
\mathrm{C}_{3} \mathrm{H} 10 \mathrm{~T}_{1 / 2} \text { cells by neutrons and } \\
\text { charged particles of defined LETs }\end{array}$ & 2.0 \\
\hline 58. & B. Loucas & CRR & Bio & $\begin{array}{l}\text { Breakage and rejoining of interphase } \\
\text { chromatin in non-cycling human } \\
\text { fibroblasts as a function of LET }\end{array}$ & 11.8 \\
\hline 59. & D. Grunberger & $\begin{array}{l}\text { Columbia } \\
\text { University }\end{array}$ & Bio & $\begin{array}{l}\text { Induction by radon daughter alpha } \\
\text { particles of mutations in the } \\
\text { dihydrofolate reductase gene of } \\
\text { Chinese hamster ovary cells in culture }\end{array}$ & 5.5 \\
\hline 60. & I. B. Weinstein & $\begin{array}{l}\text { Columbia } \\
\text { University }\end{array}$ & $\overline{\text { Bio }}$ & $\begin{array}{l}\text { Effects of alpha-particle irradiations } \\
\text { on mammalian cells (mutation) }\end{array}$ & 8.0 \\
\hline 61. & J. Ward & $\overline{\text { UCSD }}$ & Chem & $\begin{array}{l}\text { Double and single strand chromosome } \\
\text { breakage from alpha-particle } \\
\text { irradiation }\end{array}$ & 3.0 \\
\hline 62. & Z. Ronai & $\begin{array}{l}\text { American } \\
\text { Health } \\
\text { Foundation }\end{array}$ & Bio & $\begin{array}{l}\text { Radon effects on gene expression in } \\
\text { hamster clara cells }\end{array}$ & 0.5 \\
\hline$\cdots$ & J. DiCello & $\begin{array}{l}\text { Clarkson } \\
\text { University }\end{array}$ & Phys & $\begin{array}{l}\text { Single event upsets (SEUs) caused by } \\
\text { monoenergetic neutrons in computer } \\
\text { memory chips }\end{array}$ & 2.1 \\
\hline
\end{tabular}


when an experiment ran more than 10 hours on a single day. Twenty different experiments were run during these 12 months. While this is somewhat less than last year, it is still about $20 \%$ higher than the three previous years.

Nine experiments were proposed by members of the CRR, supported by grants from NIH and DOE DE-FG02-88ER60631, and eleven were proposed by outside users, supported by various grants and awards from the Department of Energy (DOE), the National Institutes of Health (NIH), the American Cancer Society (ACS), and the Lucille P. Markay Charitable Trust. In addition to research conducted by three other groups from Columbia University, experiments were performed by researchers from five other universities, two national laboratories, a foundation, and a DOE facility. Half the experimental time was used by CRR scientists and the other half by outside users. This is the third consecutive year in which outside users have accounted for half or more of the experimental time used.

The problem of radon exposure has become a topic of considerable concern and interest in recent years. Approximately one-third (6) of the experiments run at RARAF this year used ${ }^{3} \mathrm{He}$ and ${ }^{4} \mathrm{He}$ ions to investigate the effects of radon daughter decay alpha particles (Exp. 41, 53, 59, 60, 61, 62). Most of these experiments are investigating biological changes but there is also one chemistry experiment (Ward, Exp. 61). Another seven experiments (Exp. $10,37,43,50,55,56,58)$ are not specifically looking at radon effects but include a range of ${ }^{4}$ He LETs which would provide sufficient data for that purpose. Among these are measurements of both microdosimetric and nanodosimetric spectra for ${ }^{4} \mathrm{He}$ ions with various LETs.

A brief description of the experiments that have been run at RARAF since May 1, 1991 is given below.

Paul Kliauga of the CRR has begun making measurements of nanodosimetric spectra for charged particles using the track segment facility (Exp. 10). This is being performed in conjunction with the measurements of microdosimetric spectra for the "Q Project" (Exp. 37). A simple wall-less right-circular cylindrical proportional counter, consisting only of a center 
wire and a 1/8-inch diameter helix in a 9-inch diameter brass and aluminum housing, is placed in the charged particle beam. The beam enters the chamber through a $1 / 4$-inch diameter aperture covered with 6- $\mu \mathrm{m}$ thick mylar. Spectra will be obtained for a series of site sizes over the full range of available linear energy transfers (LETs).

Basil Worgul, a researcher at the Eye Radiation and Environmental Research Institute of Columbia University, repeated some of the irradiations performed last year to measure the RBE for cataract production in the lens of the rat at low doses of 0,4-MeV neutrons and to study the effect of dose fractionation (Exp. 12). These additional irradiations were required because many of the rats in the original experiment developed clouded lenses caused by drying of the eyes when the animals were anesthetized repeatedly or for more than $1 / 2$ hour. The problem was eliminated by moistening the rats' eyes with eye drops after the anesthesia was administered. Sixty five rats were irradiated with low doses of neutrons either acutely or with four fractions at 3-hour intervals. These animals are part of a lifetime study and therefore final results will not be available for about 3 years.

Paul Goldhagen of the Environmental Measurements Laboratory (EML) of DOE, in collaboration with Gerhard Randers-Pehrson of RARAF, continued variance-covariance measurements of $y_{D}$ for 14-MeV neutrons in spherical sites (Exp. 34). Using wall-less tissue-equivalent ionization chambers, measurements were made for eight simulated site sizes from about 20 to $280 \mathrm{~nm}$ diameter in order to try to determine the proximity function for 14-MeV neutrons, i.e., the distribution of distances between ionizations produced by the charged-particle recoils created by the neutrons. Considerable time was spent determining the saturation characteristics of the chambers and the contribution of dark (vacuum) currents. With 17.5 days of accelerator time, this experiment was the main user of the accelerator. Runs typically extended an extra $1 / 2$ day and even included weekends.

A project proposed by David Brenner, in collaboration with other CRR scientists, to obtain some of the basic data necessary for the estimation of the quality factor, $Q$, as a function of the microdosimetric quantity lineal energy, y, (Exp. 37) continued this year. 
Measurements of the yield of chromosome aberrations and mutations in mammalian cells exposed to a series of radiations (mostly charged-particle track segments) are being made spanning the entire range of lineal energies of interest in radiation protection. About half of the radiations can be obtained at RARAF (10 to $200 \mathrm{keV} / \mu \mathrm{m})$ and the other half are obtained at the Tandem Van de Graaff Accelerator at BNL for lineal energies not available at RARAF. Paul Kliauga is measuring the microdosimetric spectra for each radiation. Spectra for 0.5and $1-\mu \mathrm{m}$ simulated site sizes have been made for several LETs at RARAF this year using the wall-less proportional counter described for Exp. 10. Irradiations of human skin fibroblasts with $120-\mathrm{keV} / \mu \mathrm{m}{ }^{4} \mathrm{He}$ ions have been performed. Biological results will be unfolded using the measured microdosimetric spectra to give a response function, $q(y)$, which can be used to predict the results for any radiation whose microdosimetric spectrum is known. This will be tested using the results of irradiations with $14-\mathrm{MeV}$ neutrons, which produce secondary particles having a wide range of LETs.

Two different experiments have been performed initially by Richard Miller, formerly of the CRR and now with St. Barnabas College, and later by Stewart Martin, a new member of the CRR hired to continue much of the work Dr. Miller had been doing. The investigation of oncogenic cell transformation by alpha particles to simulate radon daughters (Exp. 41) continued, but now using fresh explants of Syrian hamster embryo cells instead of $\mathrm{C}_{3} \mathrm{H}_{10 \mathrm{~T}_{1 / 2}}$ cells. Irradiations with six different lineal energies of ${ }^{4} \mathrm{He}$ ions from 90 to 200 $\mathrm{keV} / \mu \mathrm{m}$ were made at doses as low as $10 \mathrm{mGy}$. Results statistically different from background were obtained at $20 \mathrm{mGy}$. The maximum transformation rate for cells at risk appears to be between 20 and $40 \mathrm{mGy}$. At least 60 morphologically transformed colonies have been isolated and cloned. The clones will be examined to see if they are immortalized, can grow in soft agar, and form tumors in nude mice (Exp. 55). Cells with each of these characteristics will be examined for the presence of oncogenes by Greg Fryer, also of the CRR. Human uroepithelial cells have also been irradiated, using charged particles having LETs from 20 to $120 \mathrm{keV} / \mu \mathrm{m}$. Cells are injected into nude mice as the assay for 
tumorigenicity; they do not show morphological transformation in culture. At least one tumor has been found as a result of single dose irradiation.

Two other experiments proposed by Richard Miller, both involving $\mathrm{C}_{2} \mathrm{H}_{10} \mathrm{~T}_{1 / 2}$ cell transformation, were run this year. An investigation to determine the effect of dose fractionation on transformation using charged particles with different LETs (Exp. 50) concluded, at least temporarily, this year. Cells were irradiated in three fractions with separation times between fractions ranging from 18 seconds to $2 \frac{1}{2}$ hours. An increase in transformation was seen only for irradiations using particles with LETs between 40 and 120 $\mathrm{keV} / \mu \mathrm{m}$. The level of enhancement increases with the time between fractions until 90 minutes separation time, after which it remains constant. Another experiment, to determine cell transformation as a function of cell cycle (Exp. 56), has recently begun. Cells syrichronized by mitotic shake-off are irradiated with $0.6 \mathrm{~Gy}$ of $6-\mathrm{MeV}$ neutrons at various times after synchronization. Little variation in cell survival was observed with position in the cell cycle. Initial results indicate that transformation of cells in $G_{2}$ phase may be about 4-5 times more sensitive than cells in $S$ phase and that cells in $G_{1}$ phase may also be several times more sensitive than S-phase cells.

Tom Hei of the CRR, in collaboration with Charles Waldren of Colorado State University, continued examining the LET response of a line of human-hamster hybrid cells containing human chromosome 11 ( $\mathrm{A}_{\mathrm{L}}$ cells) over the full range of available LETs (Exp. 43). Cells are scored at both the HGPRT and S1 loci. Southern blot analysis of both types of mutants is being performed by Li Zhu of the CRR. HGPRT- mutants induced by ${ }^{4} \mathrm{He}$ ions showed mostly multilocus deletions in contrast to spontaneous mutants which showed either no apparent change in the sequence or partial deletion. Similar analysis of S1- mutants using probes that map to both the long and short arms of human chromosome 11 indicates that the majority of mutants suffered massive chromosomal changes.

A trial irradiation, part of a continuing investigation begun by Victor Bond of BNL to determine the "hit size effectiveness function" (HSEF) for chromosome aberrations in 
human lymphocytes (Exp. 44), was performed this year. Lymphocytes, frozen prior to irradiation and kept frozen until processing to minimize repair, were irradiated with $0.4-\mathrm{MeV}$ monoenergetic neutrons. Styrofoam holders for the cryotubes were constructed to keep the cells from starting to thaw during the irradiations, which lasted as long as ten minutes. Doses from 10 to $100 \mathrm{mGy}$ were delivered. DNA from individual cells will be examined by gel electrophoresis to determine if cells that have been "hit" by charged-particle recoils from the neutrons can be distinguished from cells that have not been "hit".

Angel Pellicer of New York University continued a study of mutations produced by monoenergetic neutrons (Exp. 45). C57 black 6 and mus. spreadus strains of mice were irradiated with $0.4-\mathrm{MeV}$ neutrons to confirm that they would produce thymic lymphomas as did the RF/J strain used previously. Offspring crossbred from these two strains were to be irradiated and thymic lymphomas analyzed for the activation of dominant oncogenes or the inactivation of recessive oncogenes. Unfortunately, after several attempts, no lymphomas were produced in either of the parent strains and the experiment is currently inactive due to lack of funding.

An investigation by Charles Geard of the CRR of chromosome aberrations in CHO and human cells using the soft X-ray facility (Exp. 51) continued this year. X-rays generated using methane (carbon) and neon targets have very similar mass attenuation coefficients in tissue but the secondary electrons ( 277 and $849 \mathrm{eV}$ ) have quite different track lengths. The effectiveness of these radiations can be readily intercompared because the dose attenuation through the cells, though quite large, is nearly the same for both energies. Comparison with other radiations still requires a good estimate of the "true" dose in the cells. Irradiations were performed this year with neon $\mathrm{X}$ rays.

A collaboration between James Willey of the University of Rochester, Tom Hei of the CRR, and Chang Qing Piao, a guest scientist from the Institute for Radiation, Beijing, The People's Republic of China, is examining the oncogenic transformation of an immortalized human bronchial epithelial cell line using $150-\mathrm{keV} / \mu \mathrm{m}{ }^{4} \mathrm{He}$ ions (Exp. 53). Affter 2 to 3 
consecutive irradiations of $2 \mathrm{~Gy}$, a few anchorage-independent colonies have been isolated in soft agar. Two out of four mice inoculated with these putatively transformed cells have developed small nodules two months post irradiation.

The examination of chromosome aberrations in human lymphocytes irradiated with monoenergetic neutrons (Exp. 54) by Gayle Littlefield of Oak Ridge Associated Universities continued this year. Cells were irradiated using $1-\mathrm{MeV}$ and $2-\mathrm{MeV}$ monoenergetic neutrons with and without the addition of $\mathrm{OH}$ radical scavengers dimiethyl sulfoxide (DMSO) and WR1065. Changes in cell cycle delay with neutron energy will be examined as well as how cell cycle kinetics are ameliorated under conditions of maximum $\mathrm{Ol}$ radical scavenging.

Bradford Loucas of the CRR is continuing a study of chromosome breakage and rejoining kinetics as a function of charged-particle LET (Exp. 58). Using the technique of premature chromosome condensation (PCC), chromosome aberrations can be observed without requiring cells to be in mitosis so that a long time delay does not occur between the radiation damage and the observation, during which repair might occur. Confluent cultures of AG1522 human fibroblasts in $\mathrm{G}_{0}$ phase are iced within 5 minutes of irradiation to observe "initial" damage or incubated for various times after irradiation to observe repair. Initial breaks as a function of dose increase with LET, peaking at about $90-120 \mathrm{keV} / \mu \mathrm{m}$. As a function of fluence, initial breaks increase with increasing LET, reach a plateau from $90-150 \mathrm{keV} / \mu \mathrm{m}$.

An experirnent to examine the effects of radon on mutation (Exp. 59), proposed by Dezider Grunberger of the Institute of Cancer Research, was continued this year. Adelaide Carothers and Y. Ting-An of the Institute have irradiated Chinese hamster ovary (CHO) cells hemizygous for the dihydrofolate reductase (DHFR) gene with $150-\mathrm{keV} / \mu \mathrm{m}{ }^{4} \mathrm{He}$ ions using the track-segment facility. Mutant clones deficient in DHFR activity have been examined by the Southern blot technique after digestion and hybridization. The ${ }^{4} \mathrm{He}$ ions predominantly induced intragenic deletions as opposed to gamma rays which induce total locus deletions or large chromosomal inversions. Screening of all six exons amplified by polymerase chain reaction (PCR) revealed that the deletions occurred preferentially at the $3^{\prime}$ half of the gene. 
An experiment to investigate the effects of alpha particles on gene rearrangement of rat fibroblast cells (Exp. 60) was begun and completed by Bernard Weinstein and Gabrielle Windgasse of the Comprehensive Cancer Center of Columbia University. The cells contain a single copy of a transcriptionally silent reporter gene $(h p h)$ which is activated by the insertion of a promoter sequence in the region from the $5^{\prime}$ end to $h p h$. Hygromycin-containing medium is used to select the expressed gene and surviving colonies are expanded and analyzed for genetic changes using the Southern blot technique. Replicate irradiations were performed with ${ }^{4} \mathrm{He}$ ions at four LETs from 80 to $200 \mathrm{keV} / \mu \mathrm{m}$. Unfortunately, no mutated colonies were observed.

John Ward, Don Jones and Spike Milligan have continued their study of the effect of DMSO, a radical scavenger, on the relative frequency of single- and double-strand breaks due to ${ }^{4} \mathrm{He}$-ion irradiation of SV40 virus DNA and minichromosomes (Exp. 61). Aqueous solutions of DNA or minichromosomes were micro-pipetted onto a normal track-segment cell dish and made into a uniform 10- or 20- $\mu \mathrm{m}$ thick layer by putting a cover slip over the drop and spreading the liquid to the edges. Since the area of the cover slip and the volume of the liquid are known, the thickness of the liquid layer can be calculated. Samples were irradiated with various DMSO concentrations from $10^{-3}$ to $2 \mathrm{~mol} \mathrm{dm}^{-3}$. Doses as large as $6000 \mathrm{~Gy}$ of $-130 \mathrm{keV} / \mu \mathrm{m}{ }^{4} \mathrm{He}$ particles were giver to an individual sample with average dose rates as high as $20 \mathrm{~Gy} / \mathrm{s}$. Other samples were irradiated with $87-$ or $~-185-\mathrm{keV} / \mu \mathrm{m}$ ions.

A new experiment has just begun to examine the response of a DNA damageinducible gene, termed clone 3, in immortalized hamster clara cells to alpha particles (Exp. 62). Zeev Ronai and Susan Rutberg of the American Health Foundation in Valhalla, N.Y. are trying to determine the possible role of this gene in cell transformation as an aid to understanding the molecular events that occur during racion-induced transformation of human lung cells.

John Di' 'ello, in collaboration with Stephen Marino of RARAF, has done a preliminary investigation of the production of single event upsets (SEUs) in computer memory 
chips by $14-\mathrm{MeV}$ neutrons. An SEU is a correctable single-bit change in the computer memory caused by the energy deposited by a particle track, in this case secondary particles produced by the neutrons. These changes, while they do not damage the chip, do change the information contained in the chip and therefore SEUs are of great interest for space and defense computer systems. The $4 \mathrm{k}$-byte chip used for the trial is no longer of commercial interest but was selected because of the amount of data available on its response to other types of radiation. Only a total of three SEUs were observed even though over 300 Gy was delivered to the chip.

\section{Accelerator Utilization and Operation}

Accelerator usage is summarized in Table 2 and Figure 1 for the current report period as well as the seven previous periods. The accelerator was used more than $70 \%$ of the normal schedule time ( 8 hours per day, 5 days per week, excluding holidays) this year, about $12 \%$ lower than the average from 1986 to $1989,16 \%$ lower than last year, but $47 \%$ higher than for 1989-90. Unfortunately, maintenance and repairs required over $18 \%$ of the schedule time, more than double what was used in any of the last three years and also more than double the average since 1986.

Three quarters of the accelerator repair and maintenance time occurred in the four months from mid August to mid December. Except for failures of the terminal generating voltmeter motor and the new ${ }^{3} \mathrm{He}$ valve, repairs during this period were required due to recurring problems either with the ion source filament (inability to strike an arc ) or terminal voltage instability. The major cause of the trouble with the ion source was eventually traced to a small and difficult-to-locate leak in the gas supply system which kept poisoning the filament. The voltage instability was found to be caused by dirt on insulators deposited by a small leak in a hose carrying the freon used to cool the ion source, a problem we had not experienced previously which made it difficult to diagnose. 


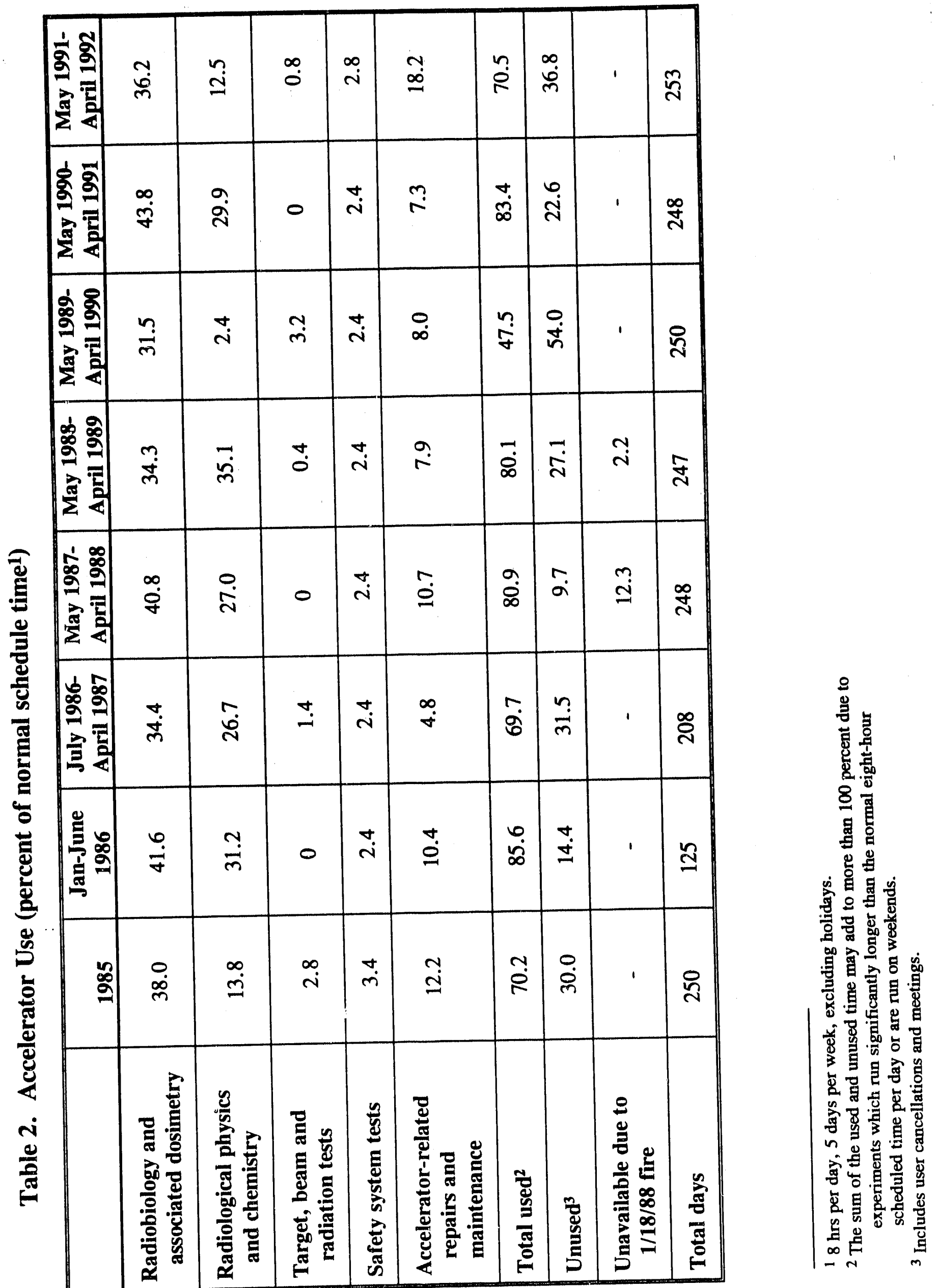




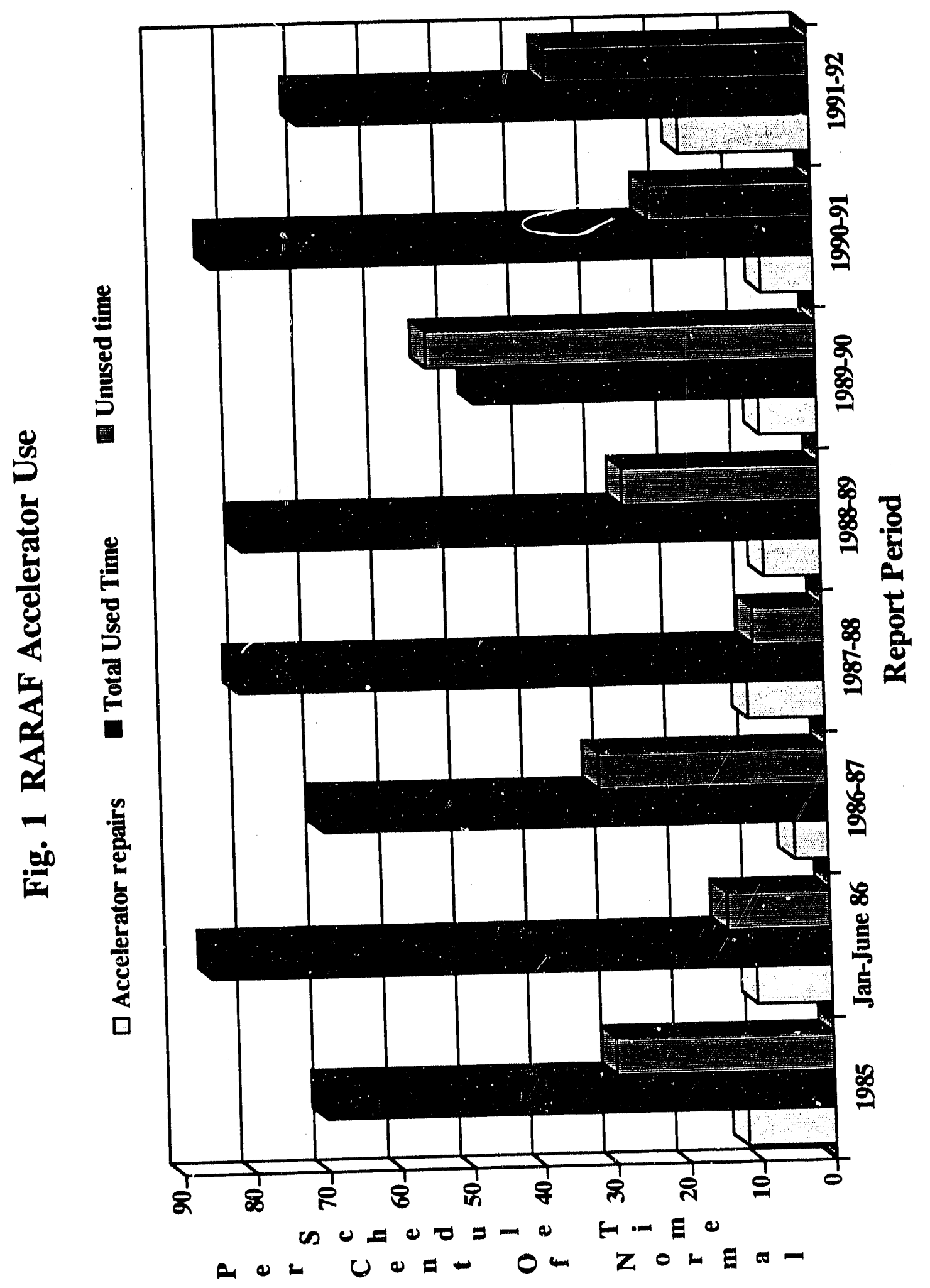


Accelerator use for radiobiology and associated dosimetry was at an average level this year and the main decrease in usage was for radiological physics and chemistry. This was primarily due to an absence of activity for several continuing physics and chemistry experiments (Exp. 2, 8', 10, 57).

The track-segment experiment at the BNL Tandem Van de Graaff Facility, related to RARAF Experiment 37, requires the absence of Stephen Marino for several one-week trips to BNL, as well as significant amounts of time for Paul Kliauga and Stewart Martin, both experimenters at RARAF. This experiment has continued to have some effect on the RARAF schedule this year, and wili probably also have an effect next year, the last year of the project.

\section{Development of Facilities}

As in the previous two years, there has been considerable time spent on the development of new capabilities. It is expected that this level of effort will continue for at least one more year.

There has been a significant amount of interest in recent years in radon exposure and the radiobiology and molecular biology of carcinogenesis and mutations caused by radondaughter alpha particles. The CRR has received a grant from NIH to improve the radonsimulation facilities at RARAF. Installation of a new gas line and valve in the Van de Graaff ion source, reported last year, has allowed us to do irradiations on the track segment facility using ${ }^{3} \mathrm{He}$ ions with an LET lower than can be attained using ${ }^{4} \mathrm{He}$ ions without losing the ability to accelerate ${ }^{4} \mathrm{He}$. Previously, to run ${ }^{3} \mathrm{He}$ required two accelerator openings: one to put ${ }^{3} \mathrm{He}$ in the reservoir in the ion source, the other to put ${ }^{4} \mathrm{He}$ back in. This would require four days of accelerator down time.

Construction of a single-particle irradiation facility, to irradiate the nuclei of individual cells with a precise number of charged particles, is also a part of this radon project supported by NIH. Design and construction of most of the beam line and irradiation facility components have been completed. 
The $50^{\circ} \mathrm{N}$ charged particle beam will be bent an additionai $70^{\circ}$ horizontally and elevated $20^{\circ}$ vertically (by tilting the magnet out of the horizontal plane) with one magnet, then bent an additional $70^{\circ}$ vertically with a second magnet into the new cell lab on the second floor. Because these two magnets are identical in construction and bend the beam through the same angle $\left(70^{\circ}\right)$, they can be run in parallel with a single existing power supply. This avoids the purchase of a $90^{\circ}$ bending magnet and a power supply, both expensive pieces of equipment. New vacuum chambers have been constructed to replace the existing ones which were only meant for a $37.5^{\circ}$ bend. A high-current switch and associated wiring have been installed to enable the power supply output to be directed either to the SH/SV area $90^{\circ}$ bending magnet or these $70^{\circ}$ bending magnets. Magnet stands have been fabricated so that the first magnet can be tilted $20^{\circ}$ from the horizontal and the second can be mounted near the ceiling of the first floor under the new cell lab. These major pieces of construction required considerable design and machining. The process of installing the new magnet stands, magnets and beam line has just begun and should be finished before the end of 1992 .

A hole has been bored in the cement floor of the new cell lab through which the vertical portion of the beam line will pass. A $3^{\prime}$ by $4^{\prime}$ air-cushion isolation table, also with a through-hole for the beam line, has been installed. The microscope and computer-controlled stage on which the cell "dishes" will be mounted have been attached to the isolation table and are being tested. These systems can be adjusted and optimized independently of the beam line construction.

\section{Personnel}

The Principal Investigator of the RARAF Grant is Eric J. Hall. The personnel of the RARAF staff, their positions, and the percerit support they receive from the RARAF Grant are given in Table 3 . 
Several people not supported by the RARAF Grant also work at the Facility. Dr. Stewart Martin, a new post-doctoral fellow at CRR, works essentially full time at RARAF, and there are two full-time biology technicians: Ms. Marcia Richards, and Mr. Marcus Geard. Dr. Richard Miller, who left Columbia University during this past year to work at St. Barnabas College, works approximately half-time at RARAF as an adjunct professor continuing many of the research projects on which he had been working.

TABLE 3. RARAF Staff

Name

Stephen Marino, M.S.

Gerhard Randers-Pehrson, Ph.D. Marie Burchett

Jesus Perez
Position

Manager, Dosimetrist Accelerator Physicist Senior Secretary Accelerator Technician
Per Cent of Support

60

70

$64^{1}$

100

1 Part time, full year.

\section{The RARAF Scientific Advisory Committee}

Toward the end of RARAF's operation at BNL, a Scientific Advisory Committee (SAC) was assembled to providc advice on how best to fulfill the scientific objectives of the Facility. The SAC, with some changes in membership, was reconvened in 1983 . Three meetings were held at Nevis Laboratories, the most recent in January, 1986. At those meetings, and by mail, the Committee made a number of general recommendations, reviewed (and approved) Experiment Requests, and provided priority ratings. The nine members of the SAC at the time of that meeting are listed on page 6 of the RARAF User's Guide.

Funding levels have made it impractical to convene further meetings of the SAC. Fortunately, strict priorities have not been necessary. This has been made possible by adept scheduling, the cooperation of users, and the dedication of the RARAF staff, who have often performed irradiations for 2, 3 or 4 different experiments with similar beam requirements on 
performed irradiations for 2,3 or 4 different experiments with similar beam requirements on the same day and have sometimes worked well into the evening and on weekends to finish experiments or repair the accelerator. 


\section{RECENT PUBLICATIONS OF WORK PERFORMED AT RARAF}

Apfel, R. E. Characterisation of new passive superheated drop (bubble) dosemeters. Tenth Symposium on Neutron Dosimetry, Radiat. Prot. Dosim. (In press).

Brenner, D. J. Radon - Current challenges in cellular radiobiology. Int. J. Radiat. Biol. 6 , 3-13, 1992.

Brenner, D. J. Radiation risk estimation at medium doses. Radiat. Res. ( Submitted 1991).

Brenner, D. J., and Hall, E. J. Radiation-induced oncogenic transformation: the interplay between dose, dose protraction, and radiation quality. Advan. Radiat. Biol. (Submitted 1992).

Brenner, D. J., Hall, E. J., Randers-Pehrson, G. and Miller, R. C. Model considerations on the dose-rate/LET dependence of Oncogenic transformation by charged particles. Radiat. Res. (Submitted 1992).

Goldhagen, P., and Randers-Pehrson, G. Variance - covariance: A practical method for microdosimetry in submicroscopic volumes. In Radiation Research; A Twentieth Century Perspective, volume II: Congress Proceedings, 9th International Congress of Radiation Research, Academic Press, pp. 415-420, 1992.

Kliauga, P. Techniques for measurement of energy deposition in nanometer volumes. In Radiation Research: A Twentieth Century Perspective, volume II: Congress Proceedings, 9th International Congress of Radiation Research, Academic Press, pp. 409-414, 1992.

Miller, R. C., Randers-Pehrson, G., Hieber, L., Marino, S. A., Richards, M. and Hall, E. J. The inverse dose-rate effect for oncogenic transformation by charged particles is LET dependent. Radiat. Res. ( Submitted 1991).

Piao, C. Q. and Hei, T. K. Radiation, cigarette smoke and oncogenic transformation. Carcinogenesis (Submitted 1992).

Sloan, R., and Pellicer, A. ras Oncogene activation in gamma - and neutron - radiation induced murine thymic lymphomas. In Radiation Research: A Twentieth Century Perspective, volume II: Congress Proceedings, 9th International Congress of Radiation Research, Academic Press, pp. 353-357, 1992. 


\section{LITERATURE CITED}

1. Rossi, H.H. and Hall, E.J. Radiological Research Accelerator Facility. USDOE Progress Report DOE/ER/60110-1 (1984).

2. Rossi, H.H. Radiological Research Accelerator Facility. USDOE Progress Report DOE/ER/60110-2 (1985).

3. Rossi, H.H., Goldhagen, P., and Hall, E.J. Radiological Research Accelerator Facility. USDOE Progress Report DOE/ER/60110-3 (1986).

4. Hall, E. J. and Goldhagen, P. Radiological Research Accelerator Facility. USDOE Progress Report DOE/ER/60439-1 (1986).

5. Hall, E.J. and Goldhagen, P. The Radiological Research Accelerator Facility. USDOE Progress Report DOE/ER/60439-2 (1987).

6. Hall, E.J. and Goldhagen, P. The Radiological Research Accelerator Facility. USDOE Progress Report DOE/ER/60631-T1 (1988).

7. Hall, E.J., Goldhagen, P., and Marino, S.A. The Radiological Research Accelerator Facility. USDOE Progress Report DOE/ER/60631-T4 (1989).

8. Hall, E.J., and Marino, S.A. The Radiological Research Accelerator Facility. USDOE Progress Report DOE/ER/60631-6 (1990).

9. Hall, E.J., and Marino, S.A. The Radiological Research Acceierator Facility. USDOE Progress Report DOE/ER/60631-8 (1991). 

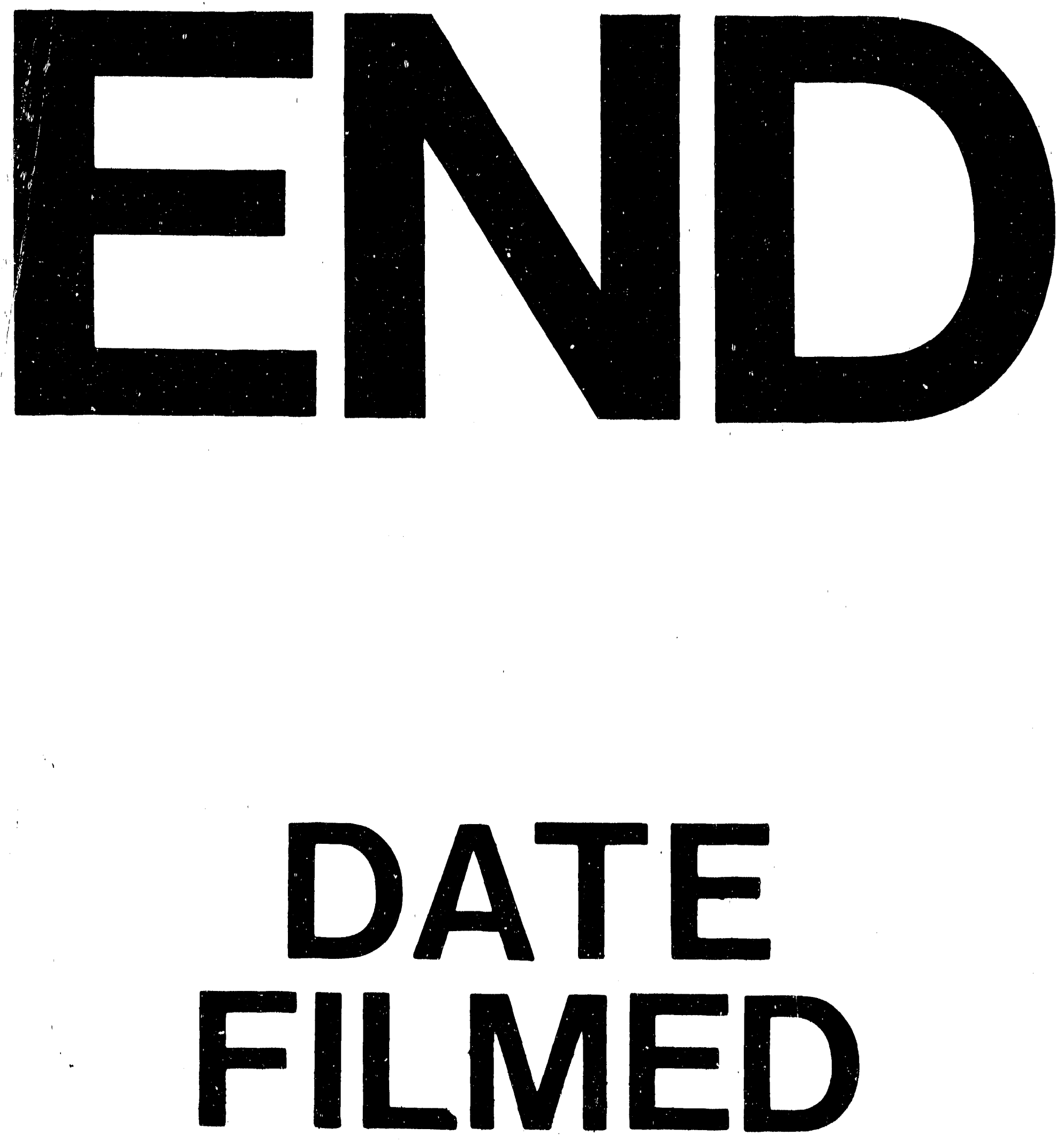

1

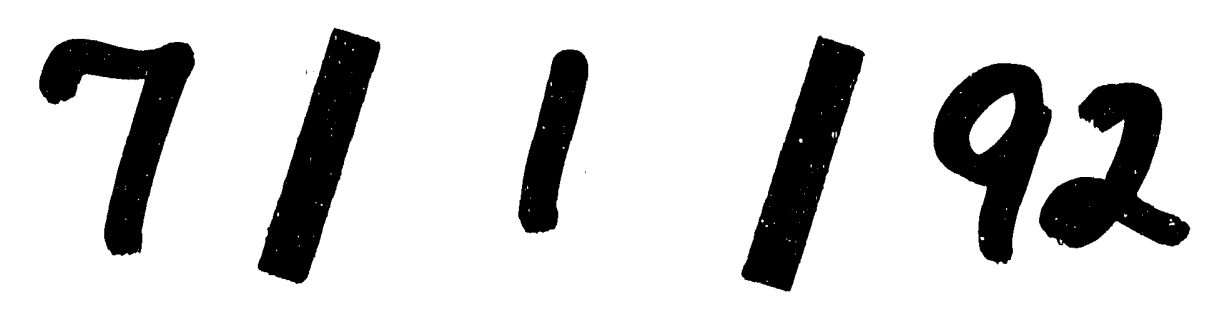


